\title{
Circular Food Behaviors: A Literature Review
}

\author{
Natália Rohenkohl do Canto ${ }^{1,2, *(\mathbb{D})}$, Klaus G. Grunert ${ }^{2,3}$ and Marcia Dutra De Barcellos ${ }^{1,2} \mathbb{D}$ \\ 1 Postgraduate Program in Management (PPGA), Federal University of Rio Grande do Sul, Porto Alegre, \\ Rio Grande do Sul 90010-460, Brazil; marcia.barcellos@ufrgs.br \\ 2 MAPP Centre, Department of Management, Aarhus University, 8210 Aarhus V, Denmark; klg@mgmt.au.dk \\ 3 School of Marketing and Communication, University of Vaasa, 65200 Vaasa, Finland \\ * Correspondence: natalia.canto@ufrgs.br
}

Citation: do Canto, N.R.; Grunert, K.G.; De Barcellos, M.D. Circular Food Behaviors: A Literature Review. Sustainability 2021, 13, 1872. https://doi.org/10.3390/su13041872

Academic Editor:

Massimiliano Borrello and

Luigi Cembalo

Received: 31 December 2020

Accepted: 4 February 2021

Published: 9 February 2021

Publisher's Note: MDPI stays neutral with regard to jurisdictional claims in published maps and institutional affiliations.

Copyright: (c) 2021 by the authors. Licensee MDPI, Basel, Switzerland. This article is an open access article distributed under the terms and conditions of the Creative Commons Attribution (CC BY) license (https:/ / creativecommons.org/licenses/by/ $4.0 /)$.

\begin{abstract}
Consumer behavior is crucial in the transition towards circular food systems. Studies so far investigate isolated circular food behaviors, but it is still unclear how the literature comprehensively addresses these behaviors. This paper provides an overview of the literature on circular food behaviors. Following a semi-systematic literature review, we analyze 46 papers related to circular food behaviors. We summarize their main features, categorize the behaviors, and propose a future research agenda. Results show the novelty and quick popularity of the topic, a dispersion across sustainability and agri-food journals, the manuscripts' goals related to consumption, a predominance of empirical data collection in Europe, a focus on behaviors related to protein alternatives, food waste, and upcycled foods, and the importance of communication and consumers' education. We categorize and characterize three types of circular food behaviors: linear, transitioning, and circular behaviors. Circular behaviors (i) are part of a systemic circular economy view, (ii) define consumers as "doers" or "prosumers", (iii) pursue long-term sustainability goals, (iv) show a high engagement of skilled consumers, and (v) are supported by technologies. Future research should consider the social dimension of sustainability and pursue a systemic view of circular food behaviors. We suggest that a circular food-related lifestyle may incorporate the recommended directions.
\end{abstract}

Keywords: circular economy; consumer behavior; food sector; circular food behavior; semi-systematic review

\section{Introduction}

The food sector impacts nature and society in several negative ways [1]. It accounts for around 30 percent of the world's total energy consumption and around 22 percent of greenhouse gas emissions [2]. Each year about 14 percent of the world's food is lost before even reaching the market, and food loss is valued at $\$ 400$ billion annually [3]. The United Nations (UN) [4] calls for an urgent need to rethink food systems and combat their inefficiencies such as food loss and waste. Several of its Sustainable Development Goals [5] — such as Goal 2 on Zero Hunger, Goal 3 on Good Health and Wellbeing, and Goal 12 on Responsible Production and Consumption [6] —relate to the food sector and strongly interrelate.

A goal particularly linked to the food sector is Goal 12, which aims to ensure sustainable consumption and production patterns. Consumers have a meaningful impact on the planet by regularly purchasing products, but current and projected material consumption rates are simply not sustainable. The impact of rising consumption coupled with the middle class's projected growth in developing countries will require even more resources [6,7]. With the world's population predicted to reach 9.1 billion people in 2050 [8], the equivalent of almost three planets could be required to provide the natural resources needed to sustain current lifestyles [2]. Food demand specifically is predicted to increase by $70 \%$ by 2050 [9], which will likely also have implications in terms of food loss and waste.

Conscious, rational, and systemic management of the food supply chain can meaningfully reduce food losses [10]. Goal 12, in particular, is very consistent with the idea of 
sustainable supply chain management since it is based on many practices commonly used in supply chains such as eco-design, use of recycling, stakeholder education, but also less frequently applied in projects that fit into the broadly understood idea of a closed-circuit economy [11].

A recent UN report shows that many food-related issues-such as hunger, undernutrition, family farmers, and sustainable agriculture-still fall short of the sustainability goals [12]. A possible solution may lie in the transition towards circular food systems, i.e., food systems that implement the circular economy's principles [13]. The circular economy refers to "an industrial system that is restorative or regenerative by intention and design" [14] (p. 7). This system pursues sustainable development by replacing "the 'end-oflife' concept with reducing, alternatively reusing, recycling, and recovering materials in production/distribution and consumption processes" [15] (p. 229).

Principato et al. [16] investigate food loss and waste valorization from a circular economy perspective in the pasta supply chain in Italy. Results show that food loss from this chain can be effectively reused for other purposes. However, the main issue remains at the consumption level-where only $25 \%$ of food wasted is reused with difficulty and ends up in landfills or, at best, being composted.

Therefore, in the transition towards sustainable food systems, consumption is crucial [17-19]. The transition towards a circular economy asks for a change in consumer behavior, increasing conscious consumption practices and green products' demand. For instance, during the COVID-19 lockdown, people who started implementing good food management practices (as shopping lists and meal planning) reduced the amount of food wasted [20] and prepared healthier food [21], showing that it is possible to transform habits and behaviors when there is control and awareness. A more substantial community involvement, public education, and proper media coverage are also critical to support circular economy initiatives [22]. Food consumption impacts human health, the environment, the economy, and society [1]. However, the literature on consumption towards circular food systems - what we refer to as circular food behaviors - is still scarce and fragmented.

Studies on circular behaviors (e.g., $[23,24])$ mostly consider products made of longlived, durable materials that are unsuitable for the environment (like metals and most plastics), also referred to as the "technical cycle" of the circular economy [14]. The literature focuses on behaviors involving Product-Service-Systems (when consumers purchase services instead of products). Some of the most popular categories of circular behaviors in the literature involve consumer electronics and car-sharing [23]. In the circular economy, consumers use, rent, and lease these products [14,25], prefer refurbished [26] or remanufactured products [27], and repair or return them after their use [23].

Many of these studies on circular behavior fail to address the food sector [23]. Food products are mainly made of biodegradable materials that can safely return to the environment (also referred to as the "biological cycle" [14]). These products are not easily subject to "servitization" [28]: Food cannot be rented, leased, refurbished, repaired, upgraded, or reused in the same way as durable goods such as mobile phones [29] or automobiles [30]. It is necessary to understand which options of circular food behaviors exist and how the consumers perceive them. Although some studies investigate isolated circular food behaviors, it is unclear how the literature comprehensively addresses these behaviors. Therefore, this paper aims to provide an overview of the literature on circular food behaviors. In a semi-systematic literature review, we summarize and discuss insights from 46 articles, categorizing the circular food behaviors and proposing a future research agenda. Our findings can help researchers refine their knowledge in this field, develop new research ideas, and provide critical skills in synthesizing existing literature.

We ultimately contribute by showing from the analysis of the papers that circular food behaviors can be categorized according to three types (or levels of development) as linear, transitioning, and circular. For each type, we identified consumers' role, sustainability goals, engagement, and technology, offering a framework to better understand the changes towards more sustainable behaviors. This research represents a valuable tool, especially 
considering the Sustainable Development Goal 12 (Responsible Production and Consumption), by showing a possible transition towards more circular behaviors, anchored in a broader understanding of consumers' roles and choices, and built up with the support of different stakeholders and technologies.

\section{Materials and Methods}

Semi-systematic reviews are useful for understanding complex areas and covering broad topics and different types of studies; they generate results as themes in literature, research agendas, and theoretical models [31]. To provide a transparent research process [31], we followed the guidelines by Tranfield et al. [32], dividing procedures into three stages: planning the review, conducting the review, and reporting and dissemination.

\subsection{Stage I: Planning the Review}

We planned the review according to the review protocol in Table 1. The protocol followed a flexible approach, making the research intentions explicit a priori but being open for changes through the study [32].

Table 1. Review protocol.

\begin{tabular}{|c|c|}
\hline Step & Description \\
\hline Research question & How does the literature approach circular food behaviors? \\
\hline Population targeted & Papers related to circular food behaviors in marketing, management, and related areas \\
\hline Search strategy & $\begin{array}{l}\text { Databases: Science Direct, EBSCO Business Source, Web of Science, and Scopus } \\
\text { Search terms a. 'circular,' 'food,' and 'consum }{ }^{* \prime} \text { in the title, abstract, and keywords }\end{array}$ \\
\hline Inclusion criteria & $\begin{array}{l}\text { Peer-reviewed journals } \\
\text { Language: English, Portuguese, Spanish, German } \\
\text { Areas: marketing, management, and related areas }\end{array}$ \\
\hline Exclusion criteria & $\begin{array}{l}\text { Repeated papers (found in more than one database) } \\
\text { Papers failing to address at least one of the topics of interest (circular economy, consumer behavior, } \\
\text { and food sector) } \\
\text { Papers in unrelated areas }\end{array}$ \\
\hline Data tabulation & $\begin{array}{l}\text { Coding categories: title, journal, year, keywords, abstract, authors, goal, theory/approach, type of } \\
\text { study (conceptual, empirical, review), methodological procedures, geographical scope of the analysis, } \\
\text { sample, concept of circular economy, consumption practices/behaviors investigated, determinants of } \\
\text { behaviors, circular products, conflicting goals/tradeoffs/barriers, main findings, practical } \\
\text { implications, limitations, future studies }\end{array}$ \\
\hline Data analysis & $\begin{array}{l}\text { Descriptive analysis } \\
\text { Content analysis }\end{array}$ \\
\hline Expected results & $\begin{array}{l}\text { Overview of the literature on circular food behaviors: } \\
\text { Summary of papers } \\
\text { Categorization of behaviors } \\
\text { Future research agenda }\end{array}$ \\
\hline
\end{tabular}

a The asterisk $\left(^{*}\right)$ used in the search terms refers to a multi-character wildcard, meaning that the search engine matches any words that fit the pattern. Based on Tranfield, Denyer, and Smart [32].

\subsection{Stage II: Conducting the Review}

This stage aimed for a comprehensive, unbiased search, resulting in a full listing of documents for the review [32]. The selection of studies started with the search of documents in January 2021 in four databases. We defined three main strings, based on the research question and population targeted (Table 1): (1) circular, to account for studies in the context of the circular economy; (2) food, since our focus was on the food sector; and (3) consum*, to include studies on consumer behavior. We aimed to search simultaneously in the title, abstract, and keywords. However, we had to adapt filters and criteria in each database 
(see Appendix A for details) because they offered different search options. We favored peer-reviewed sources to guarantee that the papers were carefully assessed.

After the search, we refined the data (Figure 1), according to Snyder's [31] third strategy. First, we removed papers duplicated across the databases; then, two independent researchers screened the titles and abstracts of the papers and checked the inclusion and exclusion criteria. The researchers individually reviewed the papers with disagreements a second time. When no consensus was reached, the researchers discussed each paper until they decided on it. This phase resulted in 53 papers. Next, we downloaded the selected papers. Two full papers could not be found (even when we contacted their authors), so they were removed from the sample. The remaining papers were fully read and mapped according to the pre-defined categories in Table 1. In this process, we discarded five papers that failed to fulfill the inclusion and exclusion criteria, resulting in a final sample of 46 papers.

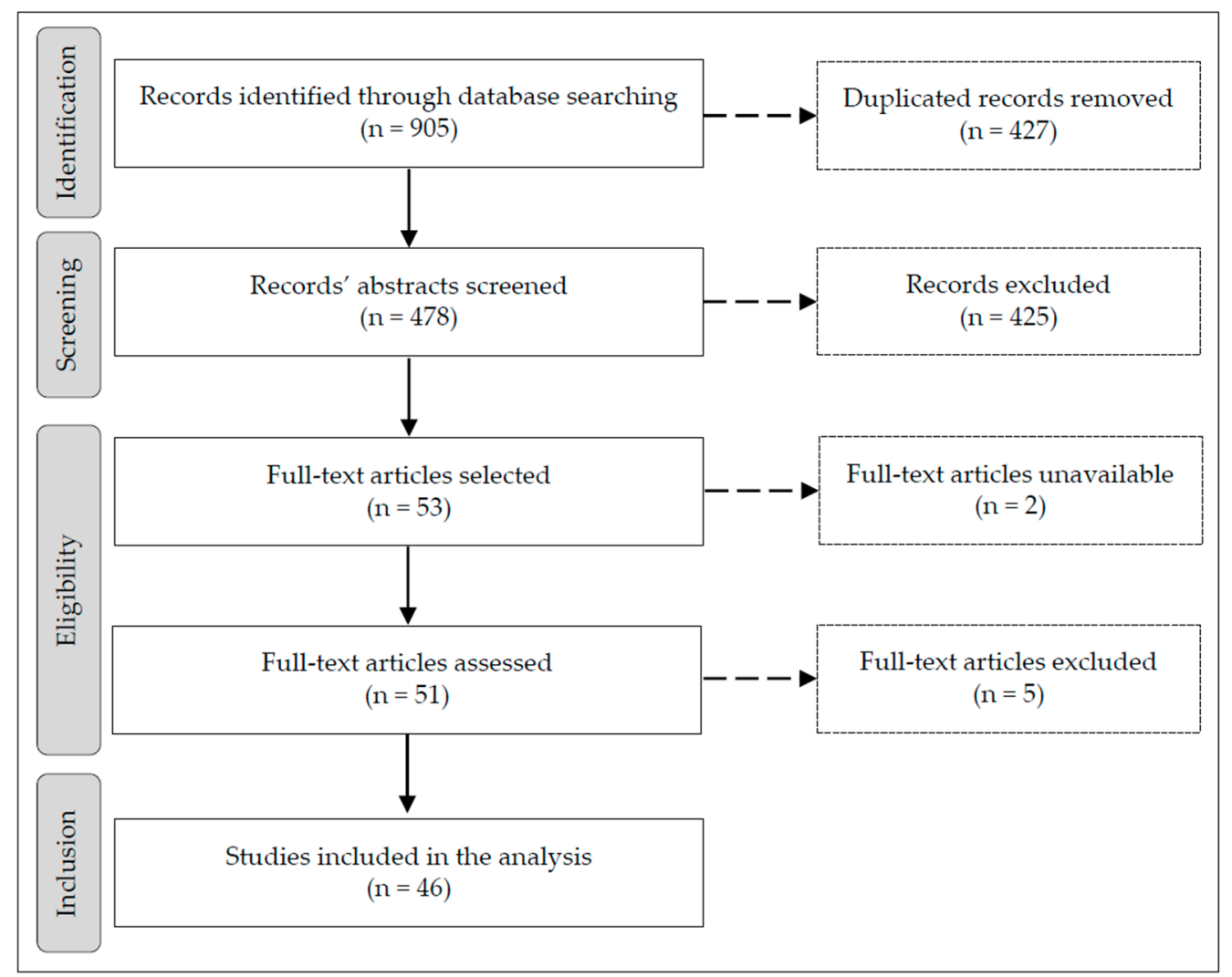

Figure 1. Methodological steps for the choice of relevant papers for the semi-systematic review. Based on PRISMA [33].

\subsection{Stage III: Reporting and Dissemination of Results}

This stage synthesized the selected information sources, simplifying the content [32]. We analyzed the content of the papers, starting with a descriptive analysis of the coded categories (Section 3.1). Next, we discussed findings according to a thematic analysis, which aggregated and summarized the studies. This stage focused on identifying and categorizing circular food behaviors (Section 3.2) and presenting a future research agenda (Section 3.3).

\section{Findings}

\subsection{Summary of Papers}

Year of publication. The papers were published from 2016 to 2020 (Figure 2). The number of papers increased through the years, with the great majority published in the last two years. This publication trend reflects the novelty and quick popularity of the topic. 


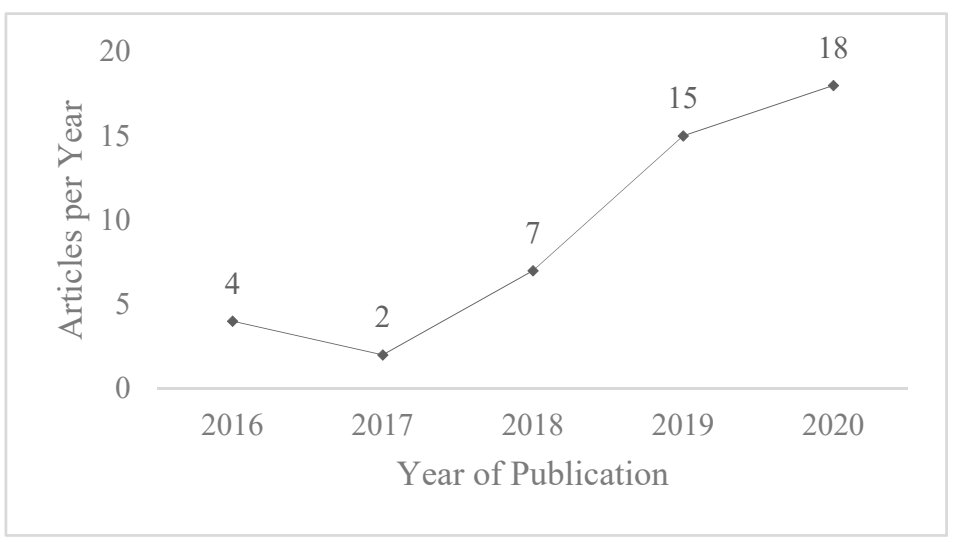

Figure 2. Circular food behaviors: article publication trends (data collected in January 2021).

Outlet. The papers were published in 29 academic journals (Table 2), demonstrating a dispersion across sources. The Journal of Cleaner Production published more papers on circular food behaviors, closely followed by Sustainability. Three other journals published more than one paper. Most journals focus on sustainability or agri-food.

Goals. The papers investigated three main types of goals: related to consumers or consumption (most frequent); unrelated to consumers, but in the circular economy context; and unrelated to consumers and circular economy, but in a related context (least frequent). Appendix B details each paper's goal.

Table 2. Journals disseminating circular food behaviors.

\begin{tabular}{lc}
\hline \multicolumn{1}{c}{ Source } & Papers \\
\hline Journal of Cleaner Production & 8 \\
Sustainability & 7 \\
Food Quality and Preference & 3 \\
Journal of Insects as Food and Feed & 2 \\
Trends in Food Science \& Technology & 2 \\
Agronomy & 1 \\
AIMS Agriculture and Food & 1 \\
Bioresource Technology & 1 \\
Current Opinion in Clinical Nutrition \& Metabolic Care & 1 \\
Current Opinion in Green and Sustainable Chemistry & 1 \\
Environmental Innovation and Societal Transitions & 1 \\
Frontiers in Environmental Science & 1 \\
Frontiers in Sustainable Food Systems & 1 \\
Geoforum & 1 \\
Global Change Biology & 1 \\
International Journal of Food Science and Technology & 1 \\
Journal of Business Ethics & 1 \\
Journal of Consumer Culture & 1 \\
Organic Agriculture & 1 \\
Packaging Technology and Science & 1 \\
PLoS ONE & 1 \\
Quality-Access to Success & 1 \\
Recent Patents on Food, Nutrition and Agriculture & 1 \\
Resources & 1 \\
Resources, Conservation and Recycling & 1 \\
Rural Society & 1 \\
Sociologia del Lavoro & 1 \\
Sustainable Production and Consumption & 1 \\
Total & 1 \\
\hline & 1 \\
\hline
\end{tabular}


Research methods. Most papers (32) collected empirical data, with fewer review and conceptual papers ( 8 and 6 each, respectively). The majority of empirical papers adopted quantitative methodologies, with surveys and experiments as the most employed research methods (Figure 3).

Geographical scope of analysis. The papers mostly targeted European countries, with Italy and the United Kingdom as the most frequently investigated countries (Table 3). Four studies investigated two or more countries, also mainly in Europe. In fourteen studies (mostly reviews and conceptual papers), the geographical scope was not described.

Behaviors explored. The papers most frequently explored behaviors related to protein alternatives (e.g., plant-based, insects as feed), food waste, and upcycled foods. Other behaviors were related to alternative food networks, food provisioning, and packaging. Fewer papers mentioned consumers' use of wild plants in nutrition, responsibility for nutrients, reduced consumption, general dietary changes, among others. Some papers explored behaviors fitting in more than one category, but most papers investigated isolated behaviors, lacking a comprehensive perspective. Appendix B lists the behaviors each paper explores.

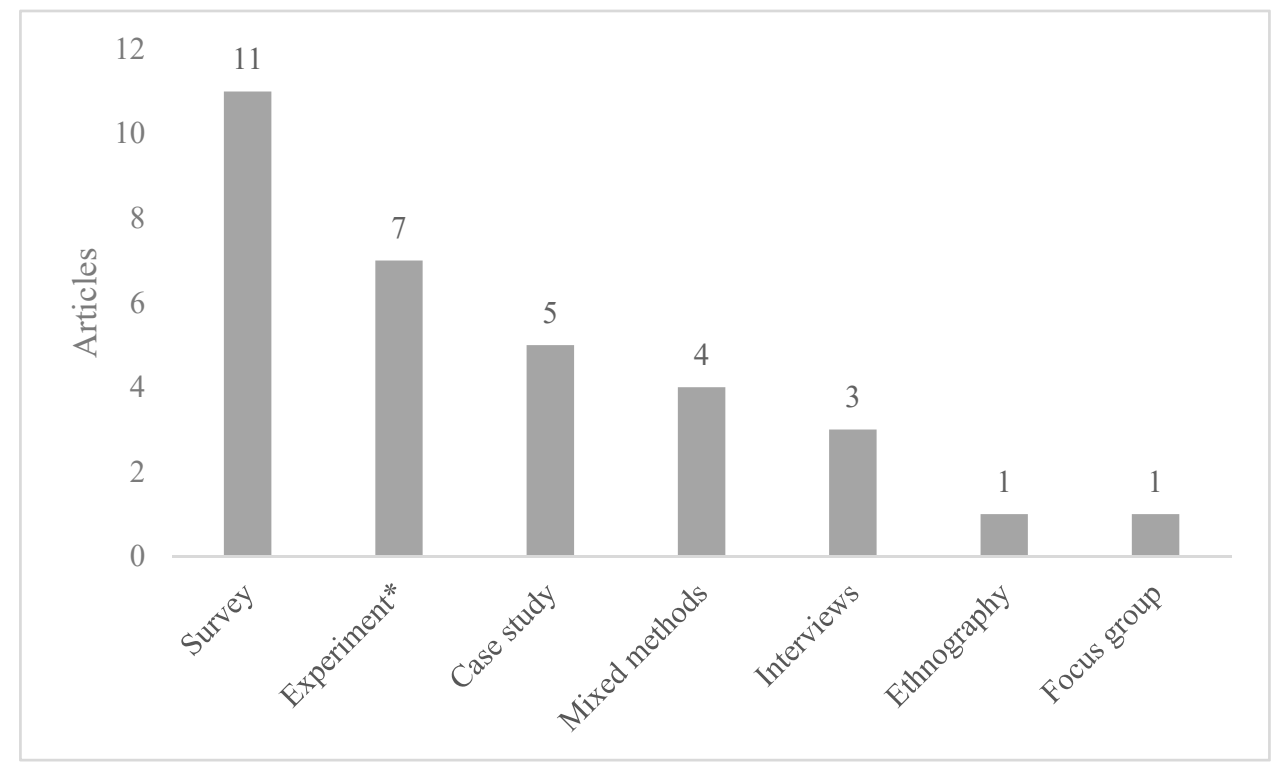

Figure 3. Research methods in the empirical papers. * Including surveys with experimental design.

Table 3. Geographical scope of analysis.

\begin{tabular}{lc}
\hline \multicolumn{1}{c}{ Investigated Country } & Papers \\
\hline Italy & 6 \\
United Kingdom & 5 \\
The Netherlands & 4 \\
Finland & 3 \\
Denmark & 2 \\
Australia & 1 \\
Belgium & 1 \\
Bulgaria & 1 \\
China & 1 \\
Hungary & 1 \\
Luxembourg & 1 \\
Norway & 1 \\
Spain & 1 \\
Multiple (two or more) & 4 \\
Total & 32 \\
\hline
\end{tabular}


Main results. Appendix B summarizes the results of each paper. Some studies identified how different variables influenced consumers' behaviors, highlighting the importance of education and communication. Other studies emphasized consumers' role in promoting circular food systems, relevant practices and products, main barriers, and the need for collaboration between stakeholders.

Some studies provided encouraging results. Cattaneo et al. [34] found a positive attitude towards the uses of food by-products (new food products with high added-value compounds recovered from food production). Russo et al. [35] found that British consumers are willing to participate in circular economy initiatives incorporating products from regenerated bio-waste. In Aschemann-Witzel and Peschel [36], communicating that a food ingredient was previously "waste" did not seem to influence consumers negatively. In another study, Peschel and Aschemann-Witzel [37] (p. 9) found that "upcycling in products can be popular among consumers". In Coderoni and Perito [38], 56\% of respondents stated to be willing to buy waste-to-value food. In Grasso and Asioli [39] (p. 5), $85 \%$ of respondents said they "would consider buying foods with upcycled ingredients". Borrello et al. $[19,28]$ found that many consumers would be willing to participate in innovative circular food loops. In Steenis et al. [40], packaging with a circular design was perceived as more sustainable than the one with a linear design and generated the most positive attitudes. Biological solutions were considered more sustainable than technical solutions [40]. Van Huis [41,42] stressed that insect-based foods are a sustainable protein alternative and present a high nutritional value and health benefits. In Sijtsema et al. [43], participants presented several motives or advantages for circular food behaviors, such as preventing food and plastic waste, economic advantages, a more social food production system, and positive feelings of helping others.

Studies also highlighted challenges. Sijtsema et al. [43] raised several objections and disadvantages consumers perceive in circular food behaviors, such as products' lack of functionality, lack of interest in participating in production systems, economic disadvantages, and risks. In Peschel and Aschemann-Witzel [37], consumers seemed unwilling to pay more for upcycled plant-based alternatives (unless there was transparency about the costs involved, but then the choice likelihood also decreased). Further challenges towards circular food behaviors related to consumers' education [44,45] and lack of knowledge and awareness $[18,43,46]$. Consumers seemed unaware of food sustainability challenges, failing to include these in their food purchase goals [47]. The lack of information-for example, on the sustainability of different packaging [48] and upcycled food ingredients [39] — showed a need to communicate better with consumers [44]. Further consumption-related barriers found were food neophobia [41,42] and food technology neophobia [17,38] (although food neophobia was not relevant in all cases, e.g., [39]); lack of acceptance of insect as a food source $[42,47,49,50]$ and food produced with upcycled ingredients $[18,39]$; globalized diets leading to inattention towards diversified, local and seasonal foods [17]; the change of shopping habits [44] and dietary choices [13]; lack of convenience [1,28,44]; adaptation to new technologies [46]; perception of risk in new food technologies [34]; lack of planning in food purchases [51]; the perceived tradeoff between sustainability and taste [36]; unfamiliarity with the "circular economy" term [43]; and the negative influence of the media [44,52].

In short, the selected papers show the novelty and quick popularity of the topic, a dispersion across sustainability or agri-food journals, goals mostly related to consumption, a predominance of empirical data collection in Europe, a focus on behaviors related to protein alternatives, food waste, and upcycled foods, the importance of consumers' education and communication, and mixed results in terms of circular food behaviors.

\subsection{Categorization of Circular Food Behaviors}

From the analysis of the papers, we offer a framework to better understand the changes towards more sustainable behaviors (Figure 4). We categorize circular food behaviors according to three types, or levels of development: linear, transitioning, and 
circular behaviors. Next, we describe the behavior types and characterize them in terms of consumers' role, sustainability goals, engagement, and technology.

\begin{tabular}{|c|c|c|c|}
\hline & Linear behaviors & Transitioning behaviors & Circular behaviors \\
\hline Definition & Follow a linear logic & $\begin{array}{l}\text { Go beyond the linear logic } \\
\text { but lack a systemic view }\end{array}$ & $\begin{array}{l}\text { Integrate into a systemic } \\
\text { view }\end{array}$ \\
\hline $\begin{array}{l}\text { Consumers' } \\
\text { role }\end{array}$ & $\begin{array}{l}\text { ‘Purchasers,' 'users,' } \\
\text { 'wasters' }\end{array}$ & 'Learners' & ‘Doers,' prosumers \\
\hline $\begin{array}{l}\text { Sustainability } \\
\text { goals }\end{array}$ & $\begin{array}{l}\text { Short-term economic goals, } \\
\text { with secondary } \\
\text { environmental or social } \\
\text { benefits }\end{array}$ & $\begin{array}{l}\text { Medium-term goals, } \\
\text { involving two } \\
\text { sustainability dimensions }\end{array}$ & $\begin{array}{l}\text { Long-term economic, } \\
\text { social, and environmental } \\
\text { goals }\end{array}$ \\
\hline Engagement & $\begin{array}{l}\text { Low engagement. } \\
\text { Consumers believe other } \\
\text { actors are responsible for } \\
\text { the impact of their } \\
\text { behaviors }\end{array}$ & $\begin{array}{l}\text { Medium engagement. } \\
\text { Consumers inform about } \\
\text { the impact of their } \\
\text { behaviors }\end{array}$ & $\begin{array}{l}\text { High engagement. } \\
\text { Consumers are skilled and } \\
\text { take responsibility for their } \\
\text { behaviors }\end{array}$ \\
\hline Technology & $\begin{array}{l}\text { Traditional technologies. } \\
\text { Low complexity }\end{array}$ & $\begin{array}{l}\text { New technologies, } \\
\text { connecting niches and } \\
\text { informing consumers. } \\
\text { Medium complexity }\end{array}$ & $\begin{array}{l}\text { Support consumers' } \\
\text { education and connection. } \\
\text { High complexity }\end{array}$ \\
\hline $\begin{array}{l}\square \text { Technology } \\
\bigcirc \text { Stakeholder } \\
\longrightarrow \begin{array}{l}\text { Material } \\
\text { flows }\end{array}\end{array}$ & & & \\
\hline
\end{tabular}

Figure 4. Transition towards circular food behaviors: three types of behaviors and their characteristics.

\subsubsection{Linear, Transitioning, and Circular Behaviors}

We distinguish three types of circular food behaviors: linear, transitioning, and circular behaviors. In this section, we define these behaviors and give some examples. The categorization is a general guide, and the examples are illustrative. A clear-cut categorization would require a more precise assessment, such as approaches combining life cycle assessment (LCA) and behavioral sciences [53] or social practice theory [54]. For instance, Di Sorrentino et al. [53] propose that LCA can integrate with behavioral science (BS) and help measuring behavior and assessing potential and means for changing behavior. This combination of LCA and BS is meaningful in terms of behavior-driven ecodesign since, in the environmental impact assessment of a product, behavioral aspects are crucial in the choice between different alternative products, the subsequent behavior of using the product, and - at the end of the use phase-in the decision how to dispose of the product. To assess sustainable consumer behavior, the authors review cognitive aspects underlying human decision making that can suggest concrete intervention for behavior change in the context of sustainable product design and policy interventions.

Linear behaviors follow a linear logic of taking-making-disposing materials [14] but contribute to the circular economy by having secondary environmental or social impacts. Examples are purchasing products that use resources more efficiently (e.g., through ecoefficiency) [40] and separating waste.

Transitioning behaviors go beyond the linear logic but lack a systemic view. The transition phase involves a mix of linear behaviors and new, circular behaviors that develop in niches. Examples are: purchasing innovative products, such as insect-based foods, upcycled food products [19,37], and foods with edible coatings [55]; purchasing less appreciated products, such as food with a non-standard aesthetics [46] or surplus food [56]; purchasing local and seasonal foods [57]; participating in alternative food networks, as packaging-free grocery shops, community-supported agriculture [57], short food chains [46,58], online groceries shopping [51], food box schemes [51,57], and digital platforms fighting food 
waste [45]; returning food waste to be upcycled $[19,59]$ in "food-product-as-a-service" approaches [28]; finding new strategies towards circularity, such as food sharing and repurposing [60]; and more radical practices, like dumpster diving [13,61]. The niche experiments that succeed in the transition phase become mainstream in the circular phase-not necessarily by upscaling these experiments since small cases might be multiplied in local communities [57].

In circular food systems, products follow a cyclical loop-for example, with packaging made of renewable material [51], or with consumers' food waste serving as insect feed, which later becomes feed for animals that re-enter the food consumption [19]. To this end, production cycles need to be redesigned and incorporate consumers [51]. In this way, what differentiates circular behaviors is that they integrate into a systemic view [51], in which broad, systemic, and economic changes are the goal. We agree with Holmes [62] and Jurgilevich [13] in that many practices to the circular economy are not novel and are already in use or recognized. To Jurgilevich et al. [13] (p. 12), the difference is that the "circular economy provides a framework in which society can create cross-sectoral policy to support varied initiatives in different 'parts of the circle' for the ultimate goal of breaking away from the linear and extractive model to a more sustainable mode of production and consumption".

Circular behaviors go beyond the individual products' choices: they are part of consumers' lifestyle [17], with consumers actively involving in initiatives that promote the circular economy. Borrello et al. [28] find that lifestyle measures (coping with risks of food provisioning, managing dependencies in food provisioning, convenience, and social pressure towards recycling) can be relevant drivers of consumers' willingness to participate in innovative circular food loops [28]. We propose that circular food behaviors imply adopting a circular food-related lifestyle, in which food consumption is part of systemic thinking. Consumers' choices are interconnected and consider a combination of factors, with the complete management of the food provisioning and diets primarily based on sustainable decisions.

\subsubsection{Consumers' Role}

The investigated papers emphasize the role of consumers in the transition towards circular food systems: "The transition to a circular economy [ ... ] requires first and foremost a change in the situation of consumers and not just that of isolated entrepreneurs" [46] (p. 129). Consumers can support circular food systems through their choices [51] in terms of lifestyle and dietary eating patterns [17]; and by accepting novel products, such as upcycled foods [37,38] and new packaging solutions [44]. Consumers may have different roles in circular food behaviors: classic customers, prosumers with flexible commitment, and compulsory volunteers [57]. We propose that these roles differ in each type of behavior.

In linear behaviors, consumers are customers [57] and owners [59] of products or services. Food consumption is centralized in supermarkets [46], with a passive purchase, use, and discard of products, and a lack of awareness about the food chain [13,19]. Consumers are "considered mere intermediaries between retailers and waste collection" [59] (p. 40).

We propose that in transitioning behaviors, consumers become "learners": they educate, learn, inform, and develop new abilities, knowledge, and competencies $[13,60]$ to support the transition towards circular food behaviors. Consumers' education seems essential in adopting new food technologies and has been associated with lower food technology neophobia [34]. By learning more about the circular economy and how to make it concrete, consumers also increase their involvement [43]. Consumers can learn about the "complexity of food consumption" and the "sustainability and health gains of sustainable diets" [63] (p. 16); they can start to "change their habits regarding the end-life of products" [59] (p. 43) and learn "what can be composted, replanted, or what is suitable for wildlife to eat" [60] (p. 10). They can learn how to interact with food products designed for circularity and change their perception of what "waste" is [56]. This learning can happen through formal education in schools, promotion campaigns in the media $[59,64,65]$, educa- 
tion policies promoted by governments [66], or even through companies' educational and engagement efforts [56]. It can also occur in niche experiments that educate consumers [57] and develop their skills and knowledge through the exchange between people [62].

In circular behaviors, consumers are "doers" of everyday activities, who incorporate food in their daily activities [60]; they become prosumers [57], which means the division between consumption and production is less clear [67]. Prosumption can imply different activities, such as volunteering to work in food initiatives and accepting the limitations of the work in the field [57].

\subsubsection{Sustainability Goals}

The circular economy aims to achieve sustainable development [15], i.e., a development that meets "the needs and aspirations of the present generation without compromising the ability of future generations to meet their needs" [68] (p. 292), implying a long-term perspective. Sustainability is also commonly divided into three dimensions: economic, environmental, and social. We propose that consumers' goals in circular food behaviors vary in terms of the time-frame and sustainability dimensions targeted.

In linear behaviors, the main focus is on short-term economic goals, which might have secondary benefits for the environment or society. People might reduce food waste, which positively impacts the environment-but their primary motivation is economic. Transitioning behaviors broaden consumers' concerns [46], who then motivate by the economic and at least one more sustainability dimension (usually the environmental). They focus on medium-term goals. We propose that circular behaviors target broad and holistic sustainability goals—-simultaneously considering long-term economic, social, and environmental aspects. So far, studies mostly neglect the social dimension, although it might enable sharing and circulating food in different ways [62]. Mylan et al. [60] (p. 11) recommend, "a move beyond the current focus on economic value and environmental costs produced by material flows, to also consider the social value generated through processes of 'consumption'". Circular food behaviors may involve social benefits such as the "provision of care, enjoyment, maintenance of traditions and connections with personal histories" [60] (p. 11) and create a community and social support [57,62]. In addition, the social aspect (such as caring for farmers' welfare) may be critical to motivate consumers to participate in circular systems [65].

\subsubsection{Engagement}

In the linear economy, consumers mostly act isolated; the circular economy presupposes their engagement. We propose that consumers' engagement gradually increases from linear to circular behaviors.

In linear behaviors, consumers have no responsibility toward products (apart from domestic recycling) [59] and believe that other actors (as companies and governments) are responsible for the environment and society [43]. Therefore, consumers adopt the options available in the market and act according to their private interests. In transitioning behaviors, consumers start to engage in niche experiments and develop, test, and disseminate them. This engagement may happen in a more flexible or binding way [57]. In niche experiments, consumers get informed about their behaviors' impact, develop skills relevant to circular food behaviors [60], and promote these experiments so that they can be upscaled [13]. In circular behaviors, consumers actively and voluntarily engage in circular practices and long-term relationships [56]. They assume responsibility for their behaviors [18,57] and for the design, use, and disposal of products [52,59] and have a set of skills that support circular food behaviors. Some niche experiments become mainstream, some remain a niche, and others disappear [13].

These different engagement levels presuppose that not only consumers get involved. Multiple stakeholders-such as industries, the government, social research, media, retailers, consumer organizations, the food and packaging design industry, and circular economy groups $[13,46,47,49,51,52,57,59,69]$ — should focus "on the collective efforts that 
are necessary to build a more resilient food system" [57] (p. 174). The behavioral changes towards circular food systems have to occur in a broad, systemic [51], economic, social [60], political [57], and cultural [1,57] level. Collaboration is the keyword, and consumers are part of it.

\subsubsection{Technology}

Technology may support circular food behaviors through innovation, connection, and education. As in the previous point, we propose that the support and complexity of technology increase from linear to circular behaviors.

Linear behaviors use traditional technologies, such as recycling and composting [19,35]. Innovations are incremental, e.g., based on reducing resources used in the production stage and end-of-pipe approaches. Consumers use technology to reproduce the linear logic-for example, to make online purchases and compare prices.

In transitioning behaviors, consumers experiment and adopt new technologies that support the circular economy. This experimentation may involve radical innovations, as insects as animal feed $[19,59]$, refrigerators and freezers with "integrated storage solutions and tools for measuring shelf life" [51] (p. 1440) or technologies in food packaging [44], such as QR codes that interact with bins and aid consumers in the disposal process [52]. Innovations are consumer-oriented and may be developed in collaborative approaches, such as co-creation [43], co-innovation, or co-design [70].

Technologies can support in new ways old modes of provision [62] or engage consumers in innovative experiments [57]. Both in transitioning and circular behaviors, technologies connect, inform, and educate consumers and have the potential to bridge the "circularity holes" in food chains [45]. They can educate about a product's benefits, indicate how and where to dispose of products [44,52], guide consumers towards healthier and more sustainable food choices [13], and increase transparency in the food chain [63]. Digital means and online communities-such as information and communications technologies, apps, digital platforms, and social networks-disseminate established practices and simplify and amplify the connections between different actors [45].

A circular economy "takes a step beyond the pursuit of waste prevention and reduction to inspire technological, organizational, and social innovation across supply chains" [35] (p. 966). Therefore, circular behaviors involve changing infrastructures and technologies that support consumption [52,60]. In the circular economy, the technologies from the transitioning phase become established and widely adopted. Innovations occur at a systemic level [18], and niche experiments become mainstream.

In sum, the main takeaway of this section is that the transition to circular food systems aims to achieve circular behaviors, which (i) are part of a systemic circular economy view, (ii) define consumers as doers or prosumers, (iii) pursue long-term sustainability goals, (iv) show a high engagement of skilled consumers, and (v) receive the support of technologies for education and connection.

\subsection{Future Research}

In the promotion of circular food behaviors, engaging consumers may be one of the greatest challenges [43]. Behaviors may involve different tradeoffs, such as investing more time and effort to behave more sustainably. Future studies should investigate ways of making circular food behaviors more familiar and attractive to consumers [43]. This greater engagement can support a systemic view of circular behaviors, which mostly lacks in the current literature.

Although we present some examples of foods and behaviors that could fit each category, the literature needs an understanding and consensus on what sustainable food is [18]. Future studies should clarify differences between circular behaviors so that consumers can have confidence in what they should do. The linear, transitioning, and circular behaviors (Figure 4) could also be explored in different ways. These behaviors' characteristics (their definition, consumers' role, engagement, and technology) could be refined-for example, 
by understanding users' willingness to adopt circular food-related technologies and the existing drivers and barriers [45]. Future studies could also check whether the proposed framework applies to other contexts than the food sector.

In terms of scope of analysis, future studies could collect data in other regions than Europe and compare results. Studies could also expand knowledge to product categories not yet investigated-for example, other upcycled and innovative food products $[36,37,39]$ or bio-based products [35]. In addition, most of the selected studies investigate isolated behaviors or products. We call future studies to address multiple behaviors, aiming to achieve a systemic view of circular food behaviors. Future studies could also use real products and realistic designs (such as field experiments) to reduce hypothetical- and social desirability biases [39]. Aschemann-Witzel et al. [17] and Grasso and Asioli [39] also recommend studies to do sensory tests so that the taste is taken into account.

Many current studies investigate the consumption of recent, hypothetical, or notyet-in-the-market innovations. Examples are waste-to-value/upcycled food products or novel ingredients in food [34,36,37,39]; a bio-fiber beer bottle [48]; a new biodegradable material based on food waste [35]; and hypothetical food waste recycling initiatives [19,28]. This shows that there is still much to understand in terms of consumers' reactions to these innovations and reinforces Kirchherr et al.'s [71] (p. 269) argument that the circular economy is a "difficult-to-implement concept" -also in terms of food consumption. Future studies should explore the feasibility of these initiatives. For example, is it technically possible to develop the innovations considered? If yes, would this be a sensible financial investment for companies? Are the other actors involved in the initiatives willing to invest the time, effort, and financial resources necessary? Does the legislation allow and support the development of these hypothetical innovations [70]? These and other factors should also be examined for each initiative before they are considered applicable (for an overview of possible challenges for the circular economy in the food sector, see [59]).

The investigated studies mostly disregard the social dimension of sustainability, a gap also found in previous reviews on the circular economy [72]. Future studies should take a better account of this dimension. Social outcomes, such as consumers' health and healthcare costs [73], could be further explored. In addition, considering that the ongoing pandemic situation has changed food consumption habits [66], studies could investigate changes in food-related lifestyle behaviors in the "post-COVID" world.

Finally, future studies should focus on behaviors with the greatest sustainability potential. The ranked lists proposed by Aiking and de Boer [1,47] (with potential improvements in the food system and current Western consumption patterns, respectively) could guide it. Although reducing consumption is considered one of the most critical strategies, few studies in our sample have investigated it. The behaviors investigated focus more on reducing food waste or the consumption of animal-based products (and substituting these with other protein alternatives [56])—but not so much on overconsumption.

\section{Discussion}

Previous reviews on circular economy called for more research on motivating consumers to participate in circular solutions [74], showed that consumers have been neglected in initial circular economy definitions [15], and suggested that circular food consumption was rarely investigated [23]. This trend seems to be reverting: our results show a growing number of studies in recent years on the topic, indicating that interest in circular food behaviors is increasing.

As in previous reviews on circular consumption [23] and circular economy in general [72], the Journal of Cleaner Production is the outlet publishing more papers. Sustainability is also among the most important journals. Differently from previous reviews, in our study, outlets related to agri-food have greater importance. This result reflects the focus on food-related behaviors. However, it also indicates that researchers on circular food consumption could direct their efforts not only for sustainability-related outlets but also towards niche-journals from different areas. 
Despite the growth in publications, room exists for expanding the knowledge in the area. Most empirical studies reviewed collect data from Europe, with few articles exploring other regions, especially emerging economies. The same issue appears in previous reviews on consumption in the circular economy [23] and circular economy in general [72,74]. China and Asia have the largest number of articles on the circular economy in the reviews by Ghisellini et al. [74] and Merli et al. [72], respectively. However, only one study in our sample targets the country, and Camacho-Otero et al. [23] also found fewer studies on circular consumption in the region. This imbalance indicates that research on circular production is not always accompanied by research on circular consumption in the same geography.

Our main contribution is to propose and characterize three types of circular food behaviors (linear, transition, and circular). All types contribute to the transition towards the circular economy, but the third one is the "ideal" to achieve. A linear logic can gain efficiency, but it also leads to "low food prices [ ... ], a lack of a connection between consumers and the food they eat, and a lack of appreciation of food as a vital source of life by consumers or food supply chain actors" [75] (p. 6471). Therefore, only a systemic logic, with changes in diets and purchase habits, may achieve a resilient, regenerative food system [73].

A systemic view of consumption may imply a lifestyle change; in the food sector, this means a new food-related lifestyle and responsible multi-stakeholder engagement. Recent studies have related the food-related lifestyle to edible insects [76] and food waste [77]. We suggest that future research expands this view to circular food behaviors by developing a circular food-related lifestyle concept.

In circular food-related lifestyles, consumers will avoid or reduce the consumption of foods with a negative environmental impact [78]. The behaviors mostly studied in the selected papers relate to protein substitution. This focus aligns with studies recommending reducing red meat production and consumption to diminish the environmental impacts of food systems and help the transition towards more sustainable food consumption patterns [79-81].

Our results support that sustainable behaviors may involve tradeoffs for consumers [82]. Usually, acting in favor of the environment is more costly in terms of time and money [83] or considered less pleasurable or convenient [82]. For example, although consumers want to avoid food waste, this usually is not prioritized when there are tradeoffs concerning taste, convenience, or health [75]. Therefore, it is essential to find ways of helping consumers to behave more sustainably, without giving up other priorities.

We also concur with the importance of educating consumers on a more practical level. People may lack the skills or knowledge to perform more sustainable behaviors in a way that just being aware of an environmental issue may not necessarily translate into behavioral changes [83]. For example, consumers present a lack of knowledge about environmentally friendly packaging, and the characteristics that make a packaging be considered "sustainable" can differ across cultures [84]. The awareness of consumers in various European countries about meat production's environmental impact is also surprisingly low [80]. Finding out the appropriate educational tools for different contexts is essential in the promotion of circular food behaviors.

\section{Conclusions}

The circular economy is a framework that can help to integrate sustainability in food systems $[13,63]$. Promoting circularity in food systems is more relevant than ever, considering that the ongoing pandemics "has highlighted the importance of sustainable food management by revealing the food system as a pivotal aspect of the sustainable supply chain" [66] (p. 9). In this sense, the literature lacked an integration of what has been studied so far in terms of circular food behaviors. This paper contributes to that by providing an overview of the literature on circular food behaviors. It summarizes the insights of 46 studies, categorizes the circular food behaviors, and proposes an agenda for 
future studies. This overview of current studies helps to understand the state-of-the-art of research and direct future efforts towards unexplored areas.

Although circular economy literature clearly emphasizes systems thinking, we see a predominance of incremental changes at consumers' and users' level. It is hard to change the existing paradigm, as some structures are highly rooted [18]. We propose that the path towards circular food behaviors could start with small changes within the current practices that support this evolution (linear behaviors), going through slightly more transformative practices (transitioning behaviors) until reaching circular practices (circular behaviors). We propose that, by understanding different behaviors that can be encouraged, it could be easier to transition towards circular food systems. The expectation of rapidly moving from linear directly to circular behaviors is probably exaggerated and unrealistic, but a smooth transition may have better chances of being welcomed and long-lasting.

We acknowledge that this paper is limited by a small sample of papers and illustrative examples of behaviors fitting in each category, without an empirical analysis that identifies which practices are the most sustainable. However, to the best of our knowledge, this is the first review addressing circular food behaviors and provides a set of future research possibilities. Future reviews could develop the theme further, for example, by applying meta-analytical designs that provide statistical analysis of the outcomes of studies.

Author Contributions: Conceptualization, K.G.G., M.D.D.B., and N.R.d.C.; methodology, N.R.d.C.; formal analysis, N.R.d.C.; investigation, N.R.d.C.; data curation, N.R.d.C.; writing-original draft preparation, N.R.d.C.; writing-review and editing, K.G.G., M.D.D.B. and N.R.d.C.; visualization, N.R.d.C.; supervision, K.G.G. and M.D.D.B.; project administration, K.G.G. and M.D.D.B.; funding acquisition, K.G.G., M.D.D.B. and N.R.d.C. All authors have read and agreed to the published version of the manuscript.

Funding: This research was funded by Aarhus University; The Brazilian National Council for Scientific and Technological Development (Conselho Nacional de Desenvolvimento Científico e Tecnológico) (CNPq), Call GM/GD, process 141414/2017-0 and Call PQ/2016, process. 306279/20169; and the Danish Agency for Science and Higher Education (Danish Government Scholarship 2018/2019).

Acknowledgments: We would like to thank Rafaela Trizotto and Cynthia Faviero for assisting in the selection of papers.

Conflicts of Interest: The authors declare no conflict of interest. 


\section{Appendix A}

Table A1. Data collection in the databases.

\section{EBSCO Business Source}

- $\quad$ Strings: circular AND food AND consum *

Initial search ${ }^{\mathrm{a}}$

Results' limits: Full Text Scholarly (Peer Reviewed) Journal

Partial result 378 papers

\section{Web of Science}

Science Direct

Scopus

- Strings: circular AND food AND consum

- $\quad$ Fields searched: Topic (Title, Abstract, Author Keywords and KeyWords Plus ${ }^{b}$ )

420 papers
- $\quad$ Strings: circular AND food AND (consumer OR consumption OR consume ${ }^{\mathrm{c}}$ )

- $\quad$ Fields searched: Title, abstract or author-specified keywords
- Strings: circular AND food AND consum *

Fields searched: Article title, Abstract, Keywords

184 papers

487 papers

- Research Areas: Agriculture (42), Behavioral Sciences (1), Business Economics (16), Communication (1), Cultural Studies (1), Development Studies (2), Education Educational Research (3), Environmental Sciences Ecology (147), Food Science Technology (67), International Relations (1),

- $\quad$ Language: English $(\mathrm{n}=376)$
Operations Research Management Science (3), Psycholog

(1), Public Administration (3), Science Technology Other Topics (113), Social Sciences Other Topics (1), Sociology (2), Urban Studies (4)

- $\quad$ Document types: Article (186), Editorial Material (5), Early Access (3), Review (29)
- $\quad$ Source type: Journal (432)

- $\quad$ Language: English (472), Spanish (3),

German (1), Portuguese (1)

- $\quad$ Subject areas: Agricultural and Biological Sciences (167), Arts and Humanities (5), Business, Management and Accounting (63), Decision Sciences (5), Earth and Planetary Sciences (11), Economics, Econometrics and Finance (19) Environmental Science (176), Multidisciplinary (11), Neuroscience (5), Psychology (2), Social Sciences (52)

- Document type: Article (283), Review (41), Note (3), Editorial (1), Short Survey (1) 
Table A1. Cont.

- $\quad$ Research areas: Allergy (1), Anthropology (1), Asian Studies

(1), Biochemistry Molecular Biology (11), Biodiversity

Conservation (2), Biophysics (2), Biotechnology Applied

Microbiology (11), Cell Biology (1), Chemistry (39),

Computer Science (3), Construction Building Technology (1),

Electrochemistry (1), Endocrinology Metabolism (2), Energy

Fuels (25), Engineering (87), Entomology (4), Evolutionary

Biology (2), Fisheries (14), Forestry (1), Gastroenterology

Hepatology (2), General Internal Medicine (1), Genetics

Heredity (3), Geography (2), Geology (2), Government Law

(2), Health Care Sciences Services (3), Immunology (2),

- $\quad$ Language: Lithuanian (1) and

Infectious Diseases (1), Instruments Instrumentation (1),

Exclusion
Marine Freshwater Biology (15), Materials Science (5),

Mechanics (1), Metallurgy Metallurgical Engineering (1),

Microbiology (7), Nutrition Dietetics (20), Oceanography (2),

Parasitology (1), Pharmacology Pharmacy (3), Physics (4),

Physiology (2), Plant Sciences (10), Polymer Science (1),

Physiology (2), Plant Sciences (10), Polymer Science (1),
Psychiatry (1), Public Environmental Occupational Health

Psychiatry (1), Public Environmental Occupational Health
(10), Remote Sensing (1), Robotics (1), Sport Sciences (1),

Thermodynamics (2), Toxicology (2), Tropical Medicine (1),

Veterinary Sciences (8), Virology (1), Water Resources (2),

Zoology (2)

- Document types: Proceedings Paper (20)
Article type: Book chapters (10),

Conference abstracts (4)

Encyclopedia (1), Other (1)
- $\quad$ Source type: Conference Proceeding (22), Book (22), Book Series (11), Trade Journal (2)

- $\quad$ Language: Chinese (6), French (3), Russian (1)

- $\quad$ Subject areas: Biochemistry, Genetics and Molecular Biology (69), Chemical Engineering (44), Chemistry (41), Computer Science (5), Energy (88), Engineering (92), Health Professions (3), Immunology and Microbiology (26) Materials Science (14), Mathematics (8) Medicine (44), Nursing (24), Pharmacology, Medicine (44), Nuring (24), Pharmacology, Toxicology and Pharmaceutics (14), Physic and Astronomy (5), Veterinary (9)

- Document type: Conference Paper (2)

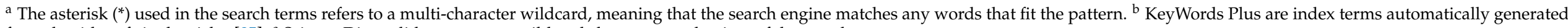
from the titles of cited articles [85]. ${ }^{\mathrm{c}}$ Science Direct did not support wildcard characters at the time of the search. 


\section{Appendix B}

Table A2. Goals, primary behaviors explored and main results of the selected papers.

\section{Source}

Goal(s)

Primary Behavior(s) Explored

To sketch why a transition from diets based

primarily on animal proteins towards diets based Adopting a diet based primarily on plan

primarily on plant proteins products is urgent for

both food security and sustainability.

To outline the role and potential contribution of insects towards food security and sustainability from a multidisciplinary perspective.

proteins products

\section{Accepting edible insects}

To explore how Danish consumers of cocoa drinks react to the use of potato and grass protein in a mock-up plant-based cocoa drink in terms of

attitude towards the product and expected quality.

Aschemann-Witzel and

Peschel [36]

To outline how sensory consumer science can contribute to the further sustainable development of food production and consumption.

Aschemann-Witzel et al. [17]
To explore business innovation for sufficiency as a means to encourage sustainable consumption.
Attitude and expected quality towards a plant-based cocoa drink

\section{Main Results}

A dietary transition from primarily animal towards plant protein products is required. New dietary guidelines are taking sustainability into account, and the contours of a diet transition are slowly emerging.

In light of the circular economy, insects are useful for food, feed, and other purposes. Health may be key to entice consumers to progress towards a diet transition. An integrated, multidisciplinary approach, including all stakeholders, remains a prerequisite.

Results show a main effect of gender and brand and an interaction of ingredients with both brand and communication, respectively. For both grass and potato proteins, the unknown brand is relatively preferred and better liked by males. Communication improves attitude towards potato drink. Brand-and product design-related differences play a role in deternin attitude to products with such new ingredients.

Six transformations to which sensory consumer science can contribute: (1) promotion of a dietary shift towards more sustainable foods and diets, (2) increase of food diverity, (3) food waste reduction, (4) enhancement of the well-being, and (6) coping with the effects of climate change.

Creation of a conceptual framework, including a range of sufficiency strategies for food. Although sufficiency implies consumption moderation, it is suggested that when a company substitutes the consumption of a less sustainable option, growth could be desirable.

To investigate how consumers living in Denmark perceive the environmental sustainability of liquid food packaging and how much they know about food packaging and how much they know about eco-labels, to compare the perceived environmenta
Slow consumption; moderate consumption; sustainable consumption.
Boesen et al. [48]
Perception of the environmental sustainability of food packaging; knowledge about eco-labels
There is a gap between Danish consumers' perception of the environmental sustainability of packaging and LCA results. Consumers have limited knowledge of sustainability-related eco-labels. 
Table A2. Cont.

Source

To illustrate an alternative to the traditional supply chain of bread based on the principles of a circular economy; to highlight the major barriers to achieving a smooth transition into a bio-based economy in the agri-food sector.

\section{Primary Behavior(s) Explored}

Returning bread leftovers and used packagin to retailers; household recycling/reuse of materials

To assess consumers' willingness to participate in strategies to reduce food waste inspired by the circular economy.

Returning food waste, purchasing circular food products

To analyze consumers' willingness to participate in an innovative food provisioning mechanism with retailers.

Willingness to participate in an innovative food provisioning mechanism with retailers

To investigate how food technology neophobia level, socio-economic variables, and information affect consumers' attitude towards uses of food by-products in relation to positive effects on the environment and consumers' health.

Attitude towards uses of food by-products

To measure to which extent circular economy strategies in Brussels Capital Region can enable climate change mitigation and understand their effect on the material footprint.

Consumption adapted to needs, improved diets, no excessive consumption

To investigate the 'circularity broker', uniting network research and circular supply chain research.

\section{Main Result}

Presentation of a framework for the bread chain with two technologies (insects as feed and degradable packaging); Seven macro-categories that summarize the main challenges which actual implementation of the model would face: regulatory limitations; reverse cycle logistics management; geographic dispersion of enterprises; system boundaries and leakages of matter; acceptance among consumers; technology development and diffusion; uncertainty of investments and incentives.

Portrait of the potential participation of consumers to closed loops inspired by the principles of the circular economy. The willingness to participate did not depend significantly on the level of innovativeness of the technology.

The expected participant is an individual already engaged in tasks to cope with risk in food provisioning and having already developed a long-lasting relation with a retailer. The study reveals the opposite effect of concerns about tasks related to take-back system, such as food waste handling, and social desirability of recycling.

Education and food technology neophobia and information can be critical in facilitating the adoption of new food technologies. Positive attitudes towards food by-products were found, even in people with a greater food neophobia and lower education level.

With circular economy-strategies on consumption or production of food, mobility, and housing, Brussels could mitigate $25 \%$ of its carbon footprint and $26 \%$ of its material footprint, $18 \%$ of its carbon footprint and $26 \%$ of its material footprint, and $7 \%$ of its carbon footprint and $10 \%$ of its material footprint, respectively.

The paper uncovers how platform organizations foster the recovery of waste by bridging circularity holes. It identifies and explicates six brokerage roles (connecting, informing, protecting, mobilizing, integrating, and measuring), and discusses them in relation to extant literature, highlighting novelties compared to earlier studies. 
Table A2. Cont.

Source

To understand the views of stakeholders from the UK food packaging supply chain towards a move to the circular economy.

Perception of food packaging, changing shopping habits, reducing food and packaging waste

To understand how packaging development

stakeholders can apply consumer behavior research Consumer engagement in the food-to-go methods within the packaging development process packaging development process; disposal o to aid the UK's food-to-go supply chain in the

To evaluate factors that favor consumer engagement in the circular economy by purchasing food-to-go packaging

Coderoni and Perito [38] waste-to-value (WTV) food.

Purchasing waste-to-value food

To explore the relative importance of 'Reward' and 'Reflection' in food orientations.

de Boer et al. [87]

To identify and systematically analyze the causal-effect relationships among barriers to circular food supply chains in China.

Farooque et al. [64] attitude towards food purchasing in Hungary.

packaging materials

Fogarassy et al. [88]

Consumers' attitude towards food purchasing

To understand the most preferred attribute composition for upcycled foods using the attributes price, type of flour, protein content and Carbon Trust label.

\section{Main Results}

Possible solutions towards the circular economy have different benefits and limitations. Transformative technologies could enable these solutions; in selecting the best solution for packaging a decision-maker must consider supply chain constraints and consumers' behaviors.

Although all stakeholders identified strengths in incorporating behavior studies in to the supply chain pack essential knowledge feedback loops, bariers to their appli instent UK waste infrastructure.

Food neophobia and food technology neophobia negatively influenced the probability of positive purchase intentions. Consumers who give importance to reading food labels and think that food could have environmental or health benefits are more likely to be willing to buy WTV food.

Giving relatively low importance to both Reward and Reflection ('routine taste') is not favorable for healthier and more sustainable diets; giving importance to Reward but not Reflection ('hedonic taste') is not better; giving importan relatively high importance to both Reward and Reflection ('reflective taste') can be a favorable, complementary combination.

Two key cause-barriers to circular food supply chains in China are weak environmental regulations and enforcement and lack of market

preference/pressure. Lack of collaboration/support from supply chain actors is the most prominent barrier.

Highly educated young people, who are conscious consumers and live on good incomes, may be the target group for circular innovation.

Consumers preferred biscuits made with wheat flour and tended to reject biscuits made with upcycled sunflower flour. Three consumers' groups were identified: (1) price sensitive consumers with the strongest preferences for low price biscuits, (2) traditionalist consumers and strongest rejences for low price biscuits, (2) tradition upcycled sunflowe-flour, (3) environmest preference for biscuits with the Carbon Trust label. Most consumers had not heard of upcycled ingredients before, but they would consider buying foods with upcycled ingredients. 
Table A2. Cont.

Source

Hebrok and Heidenstrøm [51]

To identify decisive moments and contexts within everyday practices where food waste could be prevented.

\section{Primary Behavior(s) Explored}

Food waste-related practices (acquiring, storing, assessing, valuing, and eating)

To explore how alternative modes of provisioning Participating in an alternative food

employ ordinary practices of sharing and circularity. provisioning group
Holmes [62]

Jurgilevich et al. [13]

To shed light on the concept of circular economy in the context of a circular food system

To cast light on the short supply chains' role in circular economy and sustainability.

Kiss et al. [58]

Avoiding food waste and surplus, reusing food, utilizing by-products and food waste, changing the diet, political activity

Kutkanen etal.

Lakemond et al. [49]

Lehtokunnas et al. [61]

Mak et al. [89]

To understand what hampers the transition to circular nutrient economy in Finland from the stakeholders' perspective.

Does not apply (editorial)

To examine the everyday practices of food waste

To examine the everyday practices of foo
reduction in households as ethical work.

To elucidate how circular bioeconomy can be achieved through sustainable food waste management, review the existing food waste management literature, and suggest research directions and limitations.

\section{To assess consumers' willingness to buy food} derived from underutilized biomass.

McCarthy et al. [65]

Lakemondetal.

Consuming in short food supply chains

Consuming food produced with recycled nutrients; taking responsibility for nutrients

Consuming edible insect

Household food waste practices

Food waste-related behavior
Willingness-to-buy value-added foods

\section{Main Results}

Five practices emerged as significant to food waste generation: acquiring storing, assessing, valuing, and eating. Discussion of the role of the material structures within these practices and the possible interventions.

Studying materiality is one way to illuminate new and emerging spaces of provisioning; this material focus illustrates how provisioning practices are not new but organized in original and novel ways; the materials of provisioning can be both beneficial and troublesome to provisioning organizations' practices of circulating and sharing and the extent to which organizations' practices of circulating and
they tackle social and sustainable issues.

Challenges and potential solutions. Circular economy as a framework to che circle.'

Short supply chains connect to circularity and sustainability through environmental issues, health, food quality, consumers' behavior, producer-consumer relationships, and the local economy. These factors cannot be generalized across all short chains. Their circular economic and sustainability features depend on their location, type, and individual sustainability features depend on their location, type,
attitudes of the involved consumers and producers.

The policy-governance interface lacks directionality and coordination; the enterprise-market interface creates inadequate demand articulation. The resilience of deep-rooted structures is critical.

The circular economy is a perfect vehicle to plug in edible insects, but their embedding in the whole process should be further worked out.

Results suggest that in order to understand the circular economy as a moral economy, it is crucial to note the moral complexity of everyday life that results from partly contradictory ethical sensitivities and practices.

Future developments on food waste management are expected to explore the multi-functionality of products, boundary and allocation in a circular system, and the tradeoff between food waste and resources.

Half of the sample was willing to buy value-added food. Helping Australian farmers was the top-ranking factor driving demand. Awareness of the food waste problem distinguished consumers willing to buy value-added food. 
Table A2. Cont.

Source Goal(s)

Primary Behavior(s) Explored

Main Results

To illustrate an alternative account of 'consumption' through the application of a 'sociotechnical' perspective to understanding what shapes patterns of resource use in everyday life.

Mylan et al. [60]

To analyze what consumer's characteristics influence a sustainable purchase decision.

Núñez-Cacho et al. [90]

To examine consumer attitudes towards the use of edible coatings in various sectors of the food industry.

To estimate the environmental benefits of milk sold through vending machines compared to milk sold in supermarkets, and to assess it from a

socio-economic point of view.

To investigate different degrees of transparency in communicating sustainable production practices, especially upcycling, on consumers' perceived benefit (preference) as well as companies' potentia cost and benefits (sales volume and prices charged)

Peschel andAschemann-Witzel

To quantify the main food loss and waste and their causes along the food supply chain of the pasta production; to understand if this food loss and waste could be reused according to the circular economy approach

Principato et al. [16]

To analyze four case studies of the circular and collaborative economy-type fruit and vegetable production as well as unpackaged and/or socially responsible food retail.

To give an overview on potential strategies for the promotion of edible insects as food; to portroy challenges regarding consumer acceptance of edible highlight the role of the consumer for the success of an organic-based bioeconomy.

Rumpold and Langen [50] insects in an organic-based bioeconomy; to
Domestic food provision practices

Sustainable purchase decision

Purchasing products with edible coating

Purchasing from a milk short supply chain

based on vending machines

The likelihood of choosing plant- based foods

with upcycled ingredients

Reusing and minimizing food loss and waste (FLW)

Participating in alternative food networks (AFNs)

Consumer acceptance of edible insects

Trust, willingness to eat, and overcoming disgust and neophobic reactions are central aspects to attain consumer acceptance of edible insects. Other key factors seem to be taste and other sensory aspects. instead of 'users' of products or services; and of taking account of the socia value of consumption in the principle of eco-effectiveness.

Consumers' purchase decision on the food industry is conditioned by factors such as age, sustainable behavior, knowledge of the circular economy and the perception of usefulness of plastic.

Most consumers are not familiar with edible coatings, so they would not consume foods with them. There is a need to raise consumer awareness of the benefits of edible coatings.

A short supply chain can bring environmental and socio-economic benefits, but the entrepreneurship may not suffice- the transformation towards a circular food system requires political and societal commitment.

A higher degree of transparency in communicating sustainability efforts increases product choice only to a minor degree or even affects it negatively. Fair price perception increases for upcycled alternatives, but only when cost transparency, a specific type of transparency, is disclosed. This leads to a tradeoff consisting of selling either more of the product but for lower price, or less product but at a higher value, that is, more for less or less for more.

The pasta supply chain is a good example of a circular economy as little is ost. Food losses in the field are minimal, while the straw obtained during the harvest is typically used as animal feed and litter. The losses in the grinding of the wheat and pasta production amounted to approximately $2 \%$. Most FLW occurs during the cultivation and consumption.

AFNs carve out a protected space for themselves on a small scale, allowing them to experiment and develop know-how, building networks to ground their knowledge claims onto agricultural practices and community backing. They hope to set a precedent for informed policy-making. AFNs need prosumers to make their knowledge claim strong and legitimate.
A suggestion of conceptualizing consumers as 'doers' of everyday activities,

(1)


Table A2. Cont.

Source Goal(s)

To understand consumers' intentions to purchase, pay for, and switch to products made from regenerated bio-waste.

Primary Behavior(s) Explored

Russo et al. [35]

purchase, pay for, and switch products made from regenerated bio-waste

To explore and analyze stakeholders' proposed solutions for creating sustainable agri-food systems.

Sustainable food consumption behavior

Saviolidis et al. [63]
To find the starting points for consume

Sijtsema et al. [43] involvement in activities that promote a circular economy.
Perception of circular economy and of

food-related practice cases of a circular nature.
Findings reveal no effects for product involvement and gender on the dependent variables, but for green self-identity, attitude towards bio-based products, age and past purchase experience of eco-friendly products.

Most of the identified solutions were located in the strategic tools category, reflecting shared recognition of the need to integrate food policy to achieve long-term goals. Emerging solutions-those which were most commonly identified among the different national contexts—-were used to derive empirically-grounded and more universally applicable recommendations for empirically-grounded and more universally applicable recom
the advancement of sustainable food consumption policies.

Most consumers did not have a clear understanding of the term 'circular economy'; Perceptions, attitudes, motives and barriers in terms of advantages and disadvantages varied and were related to (1) the functionalities of the products, (2) the production system, (3) economic functionalities of the products, (2) the production system, (3) economic aspects and (4) emotions such as concern about risks. The authors identified four key messages: targeting with regard to behaviors, attitudes and product functionalities, aligning with circular economy-related behavior in everyday life and involving consumers in its innovation.

The added value of circular food design model is; first, the model stimulates a citizen participation approach in a creative way; second, the model supports communication and collaboration among all involved disciplines. The newly developed circular food design model visualizes an iterative approach meant to be a flexible and creative tool to structure the new food development in the different phases to support value creation in the food system in order to support its transition.

Consumers respond favorably to more sustainable packaging redesigns, particularly biological circular improvements and less so to linear ones. Such effects are mainly driven by higher perceived sustainability, associated with greater perceived naturalness and moral satisfaction. The combinations of sustainable design strategies in packaging design follow the principle of diminishing returns.
Consuming packaging redesigned following sustainable design strategies affect consume purchase intentions.

\section{circular economy strategies}

The academic interest in insects as food and feed is growing exponentially. In addition to their high nutritional values, there are also health benefits, such as prebiotic effects of inst products, and antioxidant properties. The such as prebiotic effects of inst strategies related to consumer iss
products and making them tasty. 
Table A2. Cont.

Source

Consumption of insects as food

To assess the potential contribution of

livestock- fed with low-opportunity feedstuff-to the food supply, while reducing arable economy concept

van Zanten et al. [69]

To review global food loss and waste (FLW) and the related environmental, social, and economic impacts.

To evaluate potential changes in habitual and occasiona evalua occasional consumers in the use of wild plants in

In-home practices to reduce food loss and waste

Vilariño et al. [91] human nutrition.

Primary Behavior(s) Explored

Zarbà et al. [92]

\section{Main Results}

People in western countries are not used to eating insects, and therefore, strategies to 'convince' consumers of their hygienic safety, environmental sustainability, and tastiness are necessary. The insect sector is maturing fast, but still faces many challenges, which can only be met when all stakeholders cooperate closely.

Livestock-by recycling biomass unsuited for direct human consumption back into the food system - can potentially play a key role in feeding the future population.

The literature lacks information and evaluation of the socio-economic impact of measures and policies to reduce FLW. Lack of reliable and consistent dat and inconsistences in definitions and measurement frameworks of FLW need to be addressed.

Wild leafy 'vegetables' are included among new food lifestyles and are valued mainly due to health, popular tradition, and sustainability aspects. 


\section{References}

1. Aiking, H.; de Boer, J. The next protein transition. Trends Food Sci. Technol. 2020. [CrossRef]

2. United Nations. Goal 12. Ensure Sustainable Consumption and Production Patterns. Available online: https://www.un.org/ sustainabledevelopment/sustainable-consumption-production/ (accessed on 26 January 2021).

3. Food and Agriculture Organization of the United Nations. Food Loss and Waste Must Be Reduced for Greater Food Security and Environmental Sustainability. Available online: https:/ /www.unep.org/news-and-stories/press-release/food-loss-and-wastemust-be-reduced-greater-food-security-and (accessed on 26 January 2021).

4. United Nations. Sustainable Consumption and Production; United Nations: New York, NY, USA, 2018.

5. United Nations. Transforming Our World: The 2030 Agenda for Sustainable Development; United Nations. 2015. Available online: https://sdgs.un.org/sites/default/files/publications/21252030\%20Agenda\%20for\%20Sustainable\%20Development $\%$ 20web.pdf (accessed on 6 June 2018).

6. Fonseca, L.M.; Domingues, J.P.; Dima, A.M. Mapping the Sustainable Development Goals Relationships. Sustainability 2020, 12, 3359. [CrossRef]

7. Netherlands Enterprise Agency (NEA); Holland Circular Hotspot (HCH). Circular Economy \& SDGs: How Circular Economy Practices Help to Achieve the Sustainable Development Goals. Available online: https: / circulareconomy.europa.eu/platform/ sites/default/files/3228_brochure_sdg_-_hch_cmyk_a4_portrait_-_0520-012.pdf (accessed on 22 January 2021).

8. United Nations. World Population Prospects. Available online: https://esa.un.org/unpd/wpp/publications/files/wpp2017_ keyfindings.pdf (accessed on 1 November 2018).

9. United Nations. Water and Food Security. Available online: http://www.un.org/waterforlifedecade/food_security.shtml (accessed on 30 January 2019).

10. Zimon, D.; Madzik, P.; Domingues, P. Development of Key processes along the supply chain by implementing the ISO 22000 Standard. Sustainability 2020, 12, 6176. [CrossRef]

11. Zimon, D.; Tyan, J.; Sroufe, R. Drivers of Sustainable Supply Chain Management: Practices to Alignment with UN Sustainable Development Goals. Int. J. Qual. Res. 2020, 14, 219-236. [CrossRef]

12. United Nations. Special Edition: Progress towards the Sustainable Development Goals. 2019. Available online: https://undocs. org/E/2019/68 (accessed on 8 June 2020).

13. Jurgilevich, A.; Birge, T.; Kentala-Lehtonen, J.; Korhonen-Kurki, K.; Pietikäinen, J.; Saikku, L.; Schösler, H. Transition towards Circular Economy in the Food System. Sustainability 2016, 8, 69. [CrossRef]

14. Ellen Macarthur Foundation. Towards the Circular Economy Vol. 1: An Economic and Business Rationale for an Accelerated Transition; Ellen Macarthur Foundation. 2012. Available online: https:/ /www.ellenmacarthurfoundation.org/assets/downloads / publications / Ellen-MacArthur-Foundation-Towards-the-Circular-Economy-vol.1.pdf (accessed on 19 June 2017).

15. Kirchherr, J.; Reike, D.; Hekkert, M. Conceptualizing the circular economy: An analysis of 114 definitions. Resour. Conserv. Recycl. 2017, 127, 221-232. [CrossRef]

16. Principato, L.; Ruini, L.; Guidi, M.; Secondi, L. Adopting the circular economy approach on food loss and waste: The case of Italian pasta production. Resour. Conserv. Recycl. 2019, 144, 82-89. [CrossRef]

17. Aschemann-Witzel, J.; Ares, G.; Thøgersen, J.; Monteleone, E. A sense of sustainability? - How sensory consumer science can contribute to sustainable development of the food sector. Trends Food Sci. Technol. 2019, 90, 180-186. [CrossRef]

18. Kuokkanen, A.; Mikkilä, M.; Kahiluoto, H.; Kuisma, M.; Linnanen, L. Not only peasants' issue: Stakeholders' perceptions of failures inhibiting system innovation in nutrient economy. Environ. Innov. Soc. Transit. 2016, 20, 75-85. [CrossRef]

19. Borrello, M.; Caracciolo, F.; Lombardi, A.; Pascucci, S.; Cembalo, L. Consumers' Perspective on Circular Economy Strategy for Reducing Food Waste. Sustainability 2017, 9, 141. [CrossRef]

20. Principato, L.; Secondi, L.; Cicatiello, C.; Mattia, G. Caring more about food: The unexpected positive effect of the Covid-19 lockdown on household food management and waste. Socioecon. Plann. Sci. 2020, 100953. [CrossRef]

21. De Backer, C.J.S.; Teunissen, L.; Cuykx, I.; Decorte, P.; Pabian, S.; Gerritsen, S.; Matthys, C.; Al Sabbah, H.; Van Royen, K. An Evaluation of the COVID-19 pandemic and social distancing policies in relation to planning, selecting, and preparing healthy meals: An observational study in 38 countries worldwide. Front. Nutr. 2021. [CrossRef]

22. Fonseca, L.M.; Domingues, J.P.; Pereira, M.T.; Martins, F.F.; Zimon, D. Assessment of Circular Economy within Portuguese Organizations. Sustainability 2018, 10, 2521. [CrossRef]

23. Camacho-Otero, J.; Boks, C.; Pettersen, I.N. Consumption in the Circular Economy: A Literature Review. Sustainability 2018, 10, 2758. [CrossRef]

24. Tunn, V.S.C.; Bocken, N.M.P.; van den Hende, E.A.; Schoormans, J.P.L. Business models for sustainable consumption in the circular economy: An expert study. J. Clean. Prod. 2019, 212, 324-333. [CrossRef]

25. Edbring, E.G.; Lehner, M.; Mont, O. Exploring consumer attitudes to alternative models of consumption: Motivations and barriers. J. Clean. Prod. 2016, 123, 5-15. [CrossRef]

26. Mugge, R.; Jockin, B.; Bocken, N. How to sell refurbished smartphones? An investigation of different customer groups and appropriate incentives. J. Clean. Prod. 2017, 147, 284-296. [CrossRef] 
27. Hazen, B.T.; Mollenkopf, D.A.; Wang, Y. Remanufacturing for the Circular Economy: An Examination of Consumer Switching Behavior. Bus. Strateg. Environ. 2017, 26, 451-464. [CrossRef]

28. Borrello, M.; Pascucci, S.; Caracciolo, F.; Lombardi, A.; Cembalo, L. Consumers are willing to participate in circular business models: A practice theory perspective to food provisioning. J. Clean. Prod. 2020, 259, 121013. [CrossRef]

29. Hobson, K.; Lynch, N.; Lilley, D.; Smalley, G. Systems of practice and the Circular Economy: Transforming mobile phone product service systems. Environ. Innov. Soc. Transit. 2018, 26, 147-157. [CrossRef]

30. Matsumoto, M.; Chinen, K.; Endo, H. Comparison of U.S. and Japanese Consumers' Perceptions of Remanufactured Auto Parts. J. Ind. Ecol. 2017, 21, 966-979. [CrossRef]

31. Snyder, H. Literature review as a research methodology: An overview and guidelines. J. Bus. Res. 2019, 104, 333-339. [CrossRef]

32. Tranfield, D.; Denyer, D.; Smart, P. Towards a Methodology for Developing Evidence-Informed Management Knowledge by Means of Systematic Review. Br. J. Manag. 2003, 14, 207-222. [CrossRef]

33. PRISMA. PRISMA Statement. Available online: http:/ / www.prisma-statement.org/ (accessed on 9 June 2020).

34. Cattaneo, C.; Lavelli, V.; Proserpio, C.; Laureati, M.; Pagliarini, E. Consumers' attitude towards food by-products: The influence of food technology neophobia, education and information. Int. J. Food Sci. Technol. 2019, 54, 679-687. [CrossRef]

35. Russo, I.; Confente, I.; Scarpi, D.; Hazen, B.T. From trash to treasure: The impact of consumer perception of bio-waste products in closed-loop supply chains. J. Clean. Prod. 2019, 218, 966-974. [CrossRef]

36. Aschemann-Witzel, J.; Peschel, A.O. How circular will you eat? The sustainability challenge in food and consumer reaction to either waste-to-value or yet underused novel ingredients in food. Food Qual. Prefer. 2019, 77, 15-20. [CrossRef]

37. Peschel, A.O.; Aschemann-Witzel, J. Sell more for less or less for more? The role of transparency in consumer response to upcycled food products. J. Clean. Prod. 2020, 273, 122884. [CrossRef]

38. Coderoni, S.; Perito, M.A. Sustainable consumption in the circular economy. An analysis of consumers' purchase intentions for waste-to-value food. J. Clean. Prod. 2020, 252, 119870. [CrossRef]

39. Grasso, S.; Asioli, D. Consumer preferences for upcycled ingredients: A case study with biscuits. Food Qual. Prefer. 2020, 84, 103951. [CrossRef]

40. Steenis, N.D.; van der Lans, I.A.; van Herpen, E.; van Trijp, H.C.M.M. Effects of sustainable design strategies on consumer preferences for redesigned packaging. J. Clean. Prod. 2018, 205, 854-865. [CrossRef]

41. Van Huis, A. Nutrition and health of edible insects. Curr. Opin. Clin. Nutr. Metab. Care 2020, 23, 228-231. [CrossRef]

42. Van Huis, A. Prospects of insects as food and feed. Org. Agric. 2020. [CrossRef]

43. Sijtsema, S.J.; Snoek, H.M.; van Haaster-de Winter, M.A.; Dagevos, H. Let's Talk about Circular Economy: A Qualitative Exploration of Consumer Perceptions. Sustainability 2020, 12, 286. [CrossRef]

44. Clark, N.; Trimingham, R.; Storer, I. Understanding the views of the UK food packaging supply chain in order to support a move to circular economy systems. Packag. Technol. Sci. 2019, 32, 577-591. [CrossRef]

45. Ciulli, F.; Kolk, A.; Boe-Lillegraven, S. Circularity Brokers: Digital Platform Organizations and Waste Recovery in Food Supply Chains. J. Bus. Ethics 2020, 167, 299-331. [CrossRef]

46. Pereira, Á.; Villanueva-Rey, P.; Vence, X.; Moreira, M.T.; Feijóo, G. Fresh milk supply through vending machines: Consumption patterns and associated environmental impacts. Sustain. Prod. Consum. 2018, 15, 119-130. [CrossRef]

47. Aiking, H.; de Boer, J. Protein and sustainability-The potential of insects. J. Insects as Food Feed 2019, 5, 3-7. [CrossRef]

48. Boesen, S.; Bey, N.; Niero, M. Environmental sustainability of liquid food packaging: Is there a gap between Danish consumers' perception and learnings from life cycle assessment? J. Clean. Prod. 2019, 210, 1193-1206. [CrossRef]

49. Lakemond, C.M.M.; Veldkamp, T.; van Huis, A. Edible insects: The value chain. J. Insects Food Feed 2019, 5, 245-246. [CrossRef]

50. Rumpold, B.A.; Langen, N. Consumer acceptance of edible insects in an organic waste-based bioeconomy. Curr. Opin. Green Sustain. Chem. 2020, 23, 80-84. [CrossRef]

51. Hebrok, M.; Heidenstrøm, N. Contextualising Food Waste prevention-Decisive moments within everyday practices. J. Clean. Prod. 2019, 210, 1435-1448. [CrossRef]

52. Clark, N.; Trimingham, R.; Wilson, G.T. Incorporating Consumer Insights into the UK Food Packaging Supply Chain in the Transition to a Circular Economy. Sustainability 2020, 12, 6106. [CrossRef]

53. Di Sorrentino, E.P.; Woelbert, E.; Sala, S. Consumers and their behavior: State of the art in behavioral science supporting use phase modeling in LCA and ecodesign. Int. J. Life Cycle Assess. 2016, 21, 237-251. [CrossRef]

54. Suski, P.; Speck, M.; Liedtke, C. Promoting sustainable consumption with LCA-A social practice based perspective. J. Clean. Prod. 2021, 283, 125234. [CrossRef]

55. Pashova, S.; Radev, R.; Dimitrov, G.; Ivanov, J. Edible Coatings in Food Industry related to Circular Economy. Qual. Access Success 2018, 19, 111-117.

56. Bocken, N.; Morales, L.S.; Lehner, M. Sufficiency Business Strategies in the Food Industry-The Case of Oatly. Sustainability 2020, 12, 824. [CrossRef]

57. Reckinger, R. Social Change for Sustainable Localised Food Sovereignty: Convergence between Prosumers and Ethical Entrepreneurs. Sociol. Lav. 2018, 152, 174-192. [CrossRef]

58. Kiss, K.; Ruszkai, C.; Takács-György, K. Examination of Short Supply Chains Based on Circular Economy and Sustainability Aspects. Resources 2019, 8, 161. [CrossRef] 
59. Borrello, M.; Lombardi, A.; Pascucci, S.; Cembalo, L. The Seven Challenges for Transitioning into a Bio-based Circular Economy in the Agri-food Sector. Recent Pat. Food. Nutr. Agric. 2016, 8, 39-47. [CrossRef] [PubMed]

60. Mylan, J.; Holmes, H.; Paddock, J. Re-introducing Consumption to the "Circular Economy": A Sociotechnical Analysis of Domestic Food Provisioning. Sustainability 2016, 8, 794. [CrossRef]

61. Lehtokunnas, T.; Mattila, M.; Närvänen, E.; Mesiranta, N. Towards a circular economy in food consumption: Food waste reduction practices as ethical work. J. Consum. Cult. 2020, 1-19. [CrossRef]

62. Holmes, H. New spaces, ordinary practices: Circulating and sharing within diverse economies of provisioning. Geoforum 2018, 88, 138-147. [CrossRef]

63. Saviolidis, N.M.; Olafsdottir, G.; Nicolau, M.; Samoggia, A.; Huber, E.; Brimont, L.; Gorton, M.; Von Berlepsch, D.; Sigurdardottir H.; Del Prete, M.; et al. Stakeholder Perceptions of Policy Tools in Support of Sustainable Food Consumption in Europe: Policy Implications. Sustainability 2020, 12, 7161. [CrossRef]

64. Farooque, M.; Zhang, A.; Liu, Y. Barriers to circular food supply chains in China. Supply Chain Manag. 2019, 24, 677-696. [CrossRef]

65. McCarthy, B.; Kapetanaki, A.B.; Wang, P. Circular agri-food approaches: Will consumers buy novel products made from vegetable waste? Rural Soc. 2019, 28, 91-107. [CrossRef]

66. Giudice, F.; Caferra, R.; Morone, P. COVID-19, the Food System and the Circular Economy: Challenges and Opportunities. Sustainability 2020, 12, 7939. [CrossRef]

67. Eden, S. Blurring the boundaries: Prosumption, circularity and online sustainable consumption through Freecycle. J. Consum. Cult. 2017, 17, 265-285. [CrossRef]

68. Brundtland, G.H. Our common future-Call for action. Environ. Conserv. 1987, 14, 291-294. [CrossRef]

69. Van Zanten, H.H.E.; Herrero, M.; Van Hal, O.; Röös, E.; Muller, A.; Garnett, T.; Gerber, P.J.; Schader, C.; De Boer, I.J.M. Defining a land boundary for sustainable livestock consumption. Glob. Chang. Biol. 2018, 4185-4194. [CrossRef]

70. Sijtsema, S.J.; Fogliano, V.; Hageman, M. Tool to Support Citizen Participation and Multidisciplinarity in Food Innovation: Circular Food Design. Front. Sustain. Food Syst. 2020, 4, 1-12. [CrossRef]

71. Kirchherr, J.; Piscicelli, L.; Bour, R.; Kostense-Smit, E.; Muller, J.; Huibrechtse-Truijens, A.; Hekkert, M. Barriers to the Circular Economy: Evidence from the European Union (EU). Ecol. Econ. 2018, 150, 264-272. [CrossRef]

72. Merli, R.; Preziosi, M.; Acampora, A. How do scholars approach the circular economy? A systematic literature review. J. Clean. Prod. 2018, 178, 703-722. [CrossRef]

73. Ellen Macarthur Foundation. Growth within: A Circular Economy Vision for a Competitive Europe. 2015. Available online: https: / / www.ellenmacarthurfoundation.org/publications / growth-within-a-circular-economy-vision-for-a-competitive-europe (accessed on 4 September 2020).

74. Ghisellini, P.; Cialani, C.; Ulgiati, S. A Review on circular economy: The expected transition to a balanced interplay of environmental and economic systems. J. Clean. Prod. 2016, 114, 11-32. [CrossRef]

75. Aschemann-Witzel, J.; de Hooge, I.; Amani, P.; Bech-Larsen, T.; Oostindjer, M. Consumer-Related Food Waste: Causes and Potential for Action. Sustainability 2015, 7, 6457-6477. [CrossRef]

76. Verneau, F.; La Barbera, F.; Amato, M.; Riverso, R.; Grunert, K.G. Assessing the Role of Food Related Lifestyle in Predicting Intention towards Edible Insects. Insects 2020, 11, 660. [CrossRef] [PubMed]

77. Aschemann-Witzel, J.; de Hooge, I.E.; Almli, V.L. My style, my food, my waste! Consumer food waste-related lifestyle segments. J. Retail. Consum. Serv. 2021, 59, 102353. [CrossRef]

78. Poore, J.; Nemecek, T. Reducing food's environmental impacts through producers and consumers. Science 2018, 360, 987-992. [CrossRef]

79. Swain, M.; Blomqvist, L.; McNamara, J.; Ripple, W.J. Reducing the environmental impact of global diets. Sci. Total Environ. 2018, 610, 1207-1209. [CrossRef]

80. Hartmann, C.; Siegrist, M. Consumer perception and behaviour regarding sustainable protein consumption: A systematic review. Trends Food Sci. Technol. 2017, 61, 11-25. [CrossRef]

81. de Boer, J.; de Witt, A.; Aiking, H. Help the climate, change your diet: A cross-sectional study on how to involve consumers in a transition to a low-carbon society. Appetite 2016, 98, 19-27. [CrossRef] [PubMed]

82. Steg, L.; Bolderdijk, J.W.; Keizer, K.; Perlaviciute, G. An Integrated Framework for Encouraging Pro-environmental Behaviour: The role of values, situational factors and goals. J. Environ. Psychol. 2014, 38, 104-115. [CrossRef]

83. Thøgersen, J. Unsustainable consumption. Eur. Psychol. 2014, 19, 84-95. [CrossRef]

84. Herbes, C.; Beuthner, C.; Ramme, I. Consumer attitudes towards biobased packaging-A cross-cultural comparative study. J. Clean. Prod. 2018, 194, 203-218. [CrossRef]

85. Web of Science. Web of Science Core Collection Help. Available online: http:/ /images-webofknowledge.ez45.periodicos.capes. gov.br/ /WOKRS532MR24/help/WOS/hp_full_record.html\#dsy1028-TRS_keywords_plus (accessed on 29 May 2019).

86. Christis, M.; Athanassiadis, A.; Vercalsteren, A. Implementation at a city level of circular economy strategies and climate change mitigation-The case of Brussels. J. Clean. Prod. 2019, 218, 511-520. [CrossRef]

87. de Boer, J.; Schösler, H.; Aiking, H. Exploring the relative importance of "Reward" and "Reflection" in food orientations: Relevance for healthier and more sustainable diets. Food Qual. Prefer. 2018, 64, 126-130. [CrossRef] 
88. Fogarassy, C.; Nagy-Pércsi, K.; Ajibade, S.; Gyuricza, C.; Ymeri, P. Relations between Circular Economic "Principles" and Organic Food Purchasing Behavior in Hungary. Agronomy 2020, 10, 616. [CrossRef]

89. Mak, M.W.; Xiong, X.; Tsang, D.C.W.; Yu, I.K.M.; Poon, C.S. Sustainable food waste management towards circular bioeconomy: Policy review, limitations and opportunities. Bioresour. Technol. 2020, 297, 122497. [CrossRef] [PubMed]

90. Núñez-Cacho, P.; Leyva-Díaz, J.C.; Sánchez-Molina, J.; van der Gun, R. Plastics and sustainable purchase decisions in a circular economy: The case of Dutch food industry. PLoS ONE 2020, 15, e0239949. [CrossRef]

91. Vilariño, M.V.; Franco, C.; Quarrington, C. Food Loss and Waste Reduction as an Integral Part of a Circular Economy. Front. Environ. Sci. 2017, 5. [CrossRef]

92. Zarbà, C.; Allegra, V.; Zarbà, A.S.; Zocco, G. Wild leafy plants market survey in Sicily: From local culture to food sustainability. AIMS Agric. Food 2019, 4, 534-546. [CrossRef] 